\title{
Isolation and application of a wild strain photosynthetic bacterium to environmental waste management
}

\author{
${ }^{1,2}$ E. I. Madukasi; ${ }^{1}$ H. Chunhua; ${ }^{1 *}$ G. Zhang \\ ${ }^{1}$ State Key Laboratory of Urban Water Resource and Environment, Harbin Institute of Technology, Harbin, China \\ ${ }^{2}$ Federal Institute of Industrial Research, Oshodi, Lagos, Nigeria \\ Received 23 July 2010; ～revised 14 November 2010; accepted 24 February 2011; $\quad$ available online 1 June 2011
}

\begin{abstract}
A new photosynthetic bacterium isolate was morphologically identified as a non-motile rod-shape gram-negative bacterium. It produced a dark red culture under phototrophic condition, reproduced by budding and formed a lamellar intracytoplasmic membrane system parallel to cytoplasmic membrane, which contained bacteriochlorophyll $a$ and caratenoids. It's physiological and nutrient requirement tests gave indication that the isolate thrived and multiplied in varied environmental conditions. It was consequently named Z08 and identified as Rhodobacter sphaeroides by 16SrDNA. Adaptation of Z08 to biodegradation of two environmentally concerned wastewaters, i.e. soybean and pharmaceutical wastewaters, attested its potential in wastewater bioremediation. Z08 adaptation in a suspended batch photobioreactor treating pharmaceutical wastewater at 3500lx radiation recorded best result after wastewater dilution of 1:4 with concomitant chemical oxygen demand reduction, biomass yield and specific growth of $50 \%, 780 \mathrm{mg} / \mathrm{L}$ and $0.015 / \mathrm{h}$, respectively at the lowest hydraulic retention time of three days. Furthermore, gas chromatography mass spectra analyses of treated and raw pharmaceutical wastewater indicated that high molecular weight recalcitrant compounds found in the pharmaceutical wastewater were transformed to less toxic and acceptable lower molecular weight substances through biodegradation. Whilst Z08 treatment of soybean wastewater under natural light intensity radiation recorded $80 \%$ reduction, $1540 \mathrm{mg} / \mathrm{L}$ and $0.025 / \mathrm{h}$ for chemical oxygen demand, biomass and specific growth rate respectively regardless of the food to microorganism ratio. This preliminary investigation showed that isolate Z08 has some toxic tolerance level which could detoxify refractory substances with great potential for cell protein recovery in high organic strength wastewater. Therefore, strain Z08 could be employed in biodegradation of contaminated wastewater streams.
\end{abstract}

Keywords: Antibiotic pharmaceutical wastewater; Identification; Isolate Z08; Microbial biodegradation; Soybean wastewater

\section{INTRODUCTION}

Photosynthetic bacteria (PSB) are one of the general terms for prokaryotes holding the original photosynthetic system, which had large variety and wide distribution in the environment (Kosama and Obst, 2009). The traces of which are often observed in the paddy fields, lakes, rivers, oceans, activated sludges and soils (Okubo et al., 2006; Koblizek et al., 2008; Zhang et al., 2009). According to “Bergey's Manual of Determinative Bacteriology” (Holt et al., 1994), PSB can be divided into three families and 27 genera. They are the gram-negative (G-) bacteria with varied shapes, including spherical, rod, arc or spiral.

\footnotetext{
凶*Corresponding Author Email: gmgwen@gmail.com
}

Tel./Fax: +86151 45051945
Individual bacterium could be about 0.3 um -1.5 um in diameter or more. Propagation method of PSB is either budding or by binary split breeding. The bright colors such as purple, red and red-brown of the bacterial suspension are another important feature for PSB (Imhoff, 1992). They are special microbial category because all the PSB have in-vivo bacteriochlorophyll and carotenoids that carry out photosynthesis without oxygen production, which differentiate them from the cyanobacteria and green plants (Howard, 1987). Their photosynthesis depends on the external electron donor, such as sulfide, molecular hydrogen or organic substances. PSB have become famous for wastewater purification in recent times (Kantachote et al., 2005; 


\section{E. I. Madukasi et al.}

Yegani et al., 2005; Chae et al., 2006; Kosama and Obst, 2009), since there are two flexible metabolic pathways for them, i.e. the respiratory and the fermentative pathways (Siefert et al., 1978) which enable them to adapt to varied environmental condition. Experimental data also proved that some PSB species have high toxicity resistant level and can survive in toxic ridden wastewater whereby it utilizes the toxic substances as carbon source for growth and reproduction (Ding, 2008; Madukasi et al., 2010). The aim of this study therefore was to isolate and identify a new PSB and also to test the viability of the isolated bacterium in wastewater bioremediation utilizing two distinct industrial wastewaters including the toxic prone pharmaceutical and the organic ridden soybean wastewaters, respectively. This investigation was solely done on the isolate growth cum pollutants biodegradation using the Chemical oxygen demand (COD) as the aggregated pollutants. The research was carried out between August 2009 and July 2010 at the State Key laboratory of Urban Water Resource and Environment of Harbin Institute of Technology, China.

\section{MATERIALS AND METHODS}

Sampling and enrichment culture

The bacterial strain used in this study was isolated in a marshy soil obtained from southern China. The soil samples were collected randomly from the top soil layer and stored in closed containers at $4{ }^{\circ} \mathrm{C}$ prior to use. Microbial enrichment and isolation were performed using sterile Rhodospirillum medium (RM) as described in Table 1 (Banerjee et al., 2000).

\section{Isolation and purification of the PSB}

An enrichment culture technique was used to isolate the PSB. A mixture of $95 \mathrm{ml}$ sterile RM and $2 \mathrm{~g}$ soil were added into a $100 \mathrm{~mL}$ graduated cylinder, $5 \mathrm{~mL}$ sterile liquid paraffin was equally added on top of the solution to create anaerobic condition and incubated at $30{ }^{\circ} \mathrm{C}$ for $7 \mathrm{~d}$ under intense illumination with a $100 \mathrm{~W}$ incandescent lamp statically. After $7 \mathrm{~d}$ of incubation, the isolate was transferred into a $100 \mathrm{~mL}$ freshly prepared RM with a concentration of $840 \mathrm{mg} / \mathrm{L}$ (dry cell weight) and incubated at the same conditions 3 consecutive times until a dark red coloration was achieved. Purification of single colonies was achieved by the dilution of $1 \mathrm{~mL}$ with successive Re-streaking in a modified Sistrom minimal (RCVBN) medium (Madukasi et al., 2010) (Table 2). The RCVBN medium contained
$2 \%$ agar with malate as a sole carbon source, incubation was at $30^{\circ} \mathrm{C}$ for $48 \mathrm{~h}$ under same illumination condition prior to the cell morphology, mortality, gram-reaction and physical characterization examination. RM was sterilized by autoclaving $\left(121^{\circ} \mathrm{C}\right.$ for $\left.20 \mathrm{~min}\right)$. Nutritive agar (NA) was used for isolation, enumeration and maintenance of pure strains.

\section{Identification of photosynthetic bacteria}

The physiological and biochemical tests were done as described by Yousefi Kebria et al, (2009). Morphological and physiological characterization of the isolate was studied on nutrient agar. Gram-reaction, mortality, shape and color of the colony, oxidase activities and nutrients reduction were all examined as recommended by Fain and Haddock (2001). Carbon utilization test was carried out as recommended by Ventose et al. (1982). Internal photosynthetic membranes were identified using a Transmission electron microscope (TEM), JEM-2010, JEOL; the analysis followed the instruction manual attached to the instruments by the manufacturers. Cell pigment scans and absorption spectra of the living cells suspension were performed using cell pellets resuspended in $60 \%$ sucrose utilizing an Aminco DW200 UV-Visible spectrometer in the split mode. Cellular fatty acids analysis was carried out by Sherlock MIS specification test, brief procedure of the Sherlock MIS

Table 1: Rhodospirillum enrichment medium

\begin{tabular}{lclc}
\hline Nutrients & $\begin{array}{c}\text { Concentration } \\
(\mathrm{g} / \mathrm{L})\end{array}$ & $\begin{array}{c}\text { Vitamins and } \\
\text { minerals }\end{array}$ & $\begin{array}{c}\text { Concentration } \\
(\mathrm{g} / \mathrm{L})\end{array}$ \\
\hline $\mathrm{D}, \mathrm{L}$ malate & 4.0 & Yeast extract & 0.10 \\
$\mathrm{MgSO}_{4} .7 \mathrm{H}_{2} \mathrm{O}$ & 0.12 & $\mathrm{MnCl}_{2} .4 \mathrm{H}_{2} \mathrm{O}$ & 0.0003 \\
$\mathrm{CaCl}_{2} .2 \mathrm{H}_{2} \mathrm{O}$ & 0.076 & $\mathrm{ZnSO}_{4} .7 \mathrm{H}_{2} \mathrm{O}$ & 0.01 \\
$\mathrm{Na}_{2} \mathrm{EDTA}$ & 0.02 & $\mathrm{CoSO}_{4} .7 \mathrm{H}_{2} \mathrm{O}$ & 0.02 \\
$\mathrm{KH}_{2} \mathrm{PO}_{4}$ & 0.59 & $\mathrm{H}_{3} \mathrm{BO}_{3}$ & 0.03 \\
$\mathrm{~K}_{2} \mathrm{HPO}_{4}$ & 0.39 & $\mathrm{NaMoO}_{4} \cdot 2 \mathrm{H}_{2} \mathrm{O}$ & 0.003 \\
$\mathrm{Fe}\left(\mathrm{SO}_{4}\right)_{3} .7 \mathrm{H}_{2} \mathrm{O}$ & 0.0065 & $\mathrm{CuSO}_{4} \cdot 5 \mathrm{H}_{2} \mathrm{O}$ & 0.001 \\
\hline
\end{tabular}

Table 2: Composition of modified RCVBN medium

\begin{tabular}{|c|c|c|c|}
\hline Nutrients & $\begin{array}{l}\text { Concentration } \\
(\mathrm{g} / \mathrm{L})\end{array}$ & $\begin{array}{l}\text { Vitamins and } \\
\text { minerals }\end{array}$ & $\begin{array}{l}\text { Concentration } \\
(\mathrm{g} / \mathrm{L})\end{array}$ \\
\hline$\left(\mathrm{NH}_{4}\right)_{2} \cdot \mathrm{SO}_{4}$ & 1.0 & Biotin & 0.015 \\
\hline D,L malate & 4.0 & Yeast extract & 0.10 \\
\hline $\mathrm{MgSO}_{4} \cdot 7 \mathrm{H}_{2} \mathrm{O}$ & 0.12 & $\mathrm{MnCl}_{2} \cdot 4 \mathrm{H}_{2} \mathrm{O}$ & 0.0003 \\
\hline $\mathrm{CaCl}_{2} \cdot 2 \mathrm{H}_{2} \mathrm{O}$ & 0.076 & $\mathrm{ZnSO}_{4} \cdot 7 \mathrm{H}_{2} \mathrm{O}$ & 0.01 \\
\hline $\mathrm{Na}_{2}$ EDTA & 0.02 & $\mathrm{CoSO}_{4} .7 \mathrm{H}_{2} \mathrm{O}$ & 0.02 \\
\hline $\mathrm{KH}_{2} \mathrm{PO}_{4}$ & 0.59 & $\mathrm{H}_{3} \mathrm{BO}_{3}$ & 0.03 \\
\hline $\mathrm{K}_{2} \mathrm{HPO}_{4}$ & 0.39 & $\mathrm{NaMoO}_{4} \cdot 2 \mathrm{H}_{2} \mathrm{O}$ & 0.003 \\
\hline $\mathrm{Fe}\left(\mathrm{SO}_{4}\right)_{3} .7 \mathrm{H}_{2} \mathrm{O}$ & O 0.0065 & $\mathrm{CuSO}_{4} \cdot 5 \mathrm{H}_{2} \mathrm{O}$ & 0.001 \\
\hline
\end{tabular}


specification test is as follows: Photosynthetic isolates were cultured on Bactotryptic soy broth agar (Difco) and incubated at $28{ }^{\circ} \mathrm{C}$ for $48 \mathrm{~h}$ and the cellular fatty acids contents determined by the MIDI procedure (MIDI, Inc, New York Del). Identification of the isolates was based on a comparison of fatty acid profiles using the fatty acid profiles in tryptic soy broth agar anaerobe database (Sasser, 1990; Vladimir and Thomas, 1998).

\section{Analysis of 16SrDNA sequences}

Genomic DNA of the isolate was extracted with a GenElute DNA extraction kit from Sigma. Amplification of 16SrDNA with eubacterial universal primer 27F and 1492R was carried out (Lane, 1991). The 16SrDNA has been popular in bacterial gene identification partly because of it relatively small size which hastens sequence analysis as it saves time. Genomic DNA/PCR was performed utilizing EZ-10 Spin Column DNA purification Kit according to the manufacturer's instruction manual (Bio Basic Inc.). Sequencing was done utilizing abiprism dye terminator cycle sequencing kit with AmpliTaq DNA polymerase and an applied biosystems 373 DNA sequencer (Perkin-Elmer, Califonia, USA) The sequence was analyzed utilizing the check chimera and the similarity rank program of the Ribosomal database project (Altschul et al., 1990) to determine the closest available database sequences. Selected 16srDNA sequences were aligned using the Cluster W program (Hall, 1999). Furthermore, the phylogenic relationship of the isolate was determined by comparing the sequence data with sequences of some members of the genus Rhodopseudomonas available through the GenBank database of the Central Laboratory of the School of Municipal and Environmental Engineering, Harbin Institute of Technology. A phylogenetic tree was constructed utilizing cluster W by distance matrix analysis and the neighbor joining method (Saitou and Nei, 1987).

Application of new strain isolate Z08 in wastewater biodegradation

Z08 isolate was suspended in $500 \mathrm{~mL}$ conical flasks (photo-bioreactors) with a concentration of $840 \mathrm{mg} / \mathrm{L}$ (dry cell weight). The photo bioreactors were tightened by oxygen enriching membranes and agitated with magnetic stirrer at moderate speed; the treatment temperature varied between $25-30{ }^{\circ} \mathrm{C}$ and the $\mathrm{pH}$ was near neutral. The Dissolved oxygen (DO) was kept around $1.0 \mathrm{mg} / \mathrm{L}$ for both the soybean and the pharmaceutical wastewaters respectively. Four levels of ratio of food to microorganisms (F/M, mg-COD/mgbiomass), 49, 20, 10 and 2 were tested. The pharmaceutical wastewater bioreactor was illuminated with incandescent lamp on both sides at incident light intensity of 3500 lumens, while the soybean wastewater was treated under natural light intensity.

\section{RESULTS AND DISCUSSION}

Isolation and purification of the PSB

The successive re-streaking on RCVBN medium containing $2 \%$ agar from the enriched broth yielded three distinct red colonies (strains) that were purified consecutively. Through some experimental observations, one strain which had the best bioactivity was chosen to be used in the latter experiments and was named Z08.The cells were red and uniformly distributed in the liquid medium (Fig.1a). Whilst in the solid medium (Fig.1b), the cells were red-brown, round shape, having low convex surface, compacted edge, being moist with shiny and translucent features.

\section{Identification of the PSB}

Rehabilitation staining tests

The selected isolate named Z08 was subjected to morphological and physiological characterization. For both the single and double staining tests, optical microscopic observation of the single stained Z08 utilizing Scanning electron microscope (SEM) depicted that the cells were spheroid and the diameter of a single bacterium was about $1.0 \mu \mathrm{m} \times 2.0 \mu \mathrm{m}$. While the double staining test of the isolate showed that the isolate was $\mathrm{G}$ - species.

\section{Microscopic scanning test}

The microscopic scanning test of the isolate Z08 utilizing TEM showed clearly that the single cell isolate Z08 was spherical ellipsoid and the diameter of a single bacterial cell was about $1.0 \mu \mathrm{m} \times 1.5 \mu \mathrm{m}$. The internal photosynthetic membranes appeared lamella and lay parallel to the cytoplasmic membrane, which is an indication that the organism is a photo bacterium capable to adjust to any radiation intensity using its vacuole.

\section{Carbon source utilization of Z08}

The isolate Z08 utilized organic compounds found in the modified RCVBN medium. It grew in limited oxygen environment micro aerobically with either $\left(\mathrm{NH}_{4}\right)_{2} \mathrm{SO}_{4}$ or $\mathrm{NaNO}_{3}$ as a nitrogen source in an 


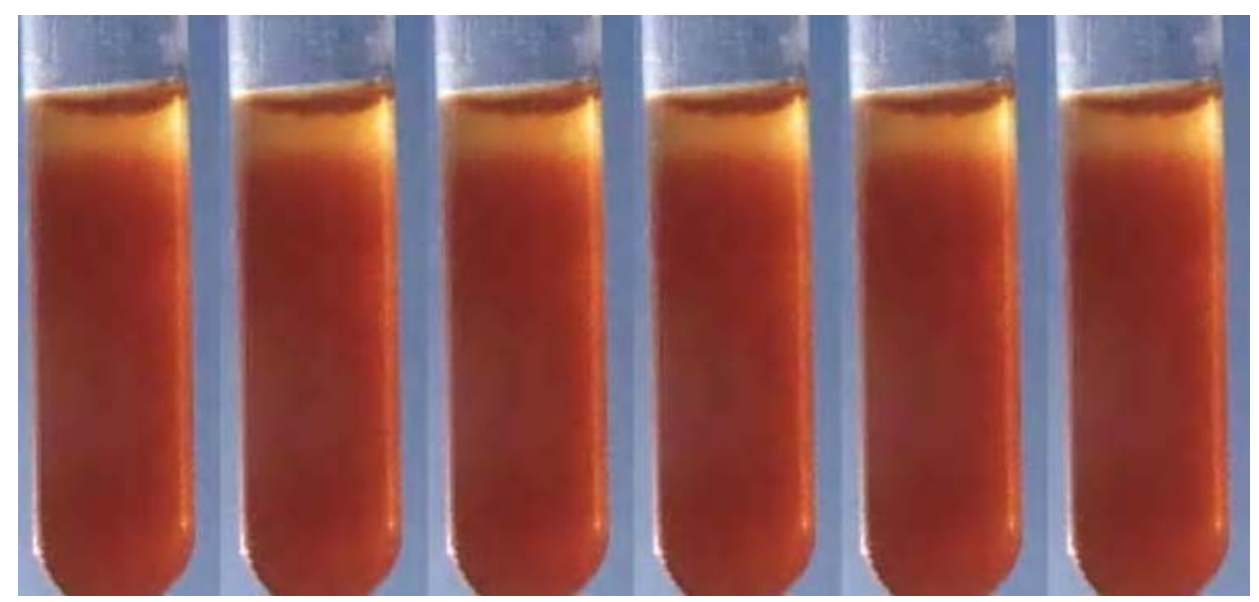

Fig. 1a: Z08 in liquid medium (modified RCVBN malate medium)

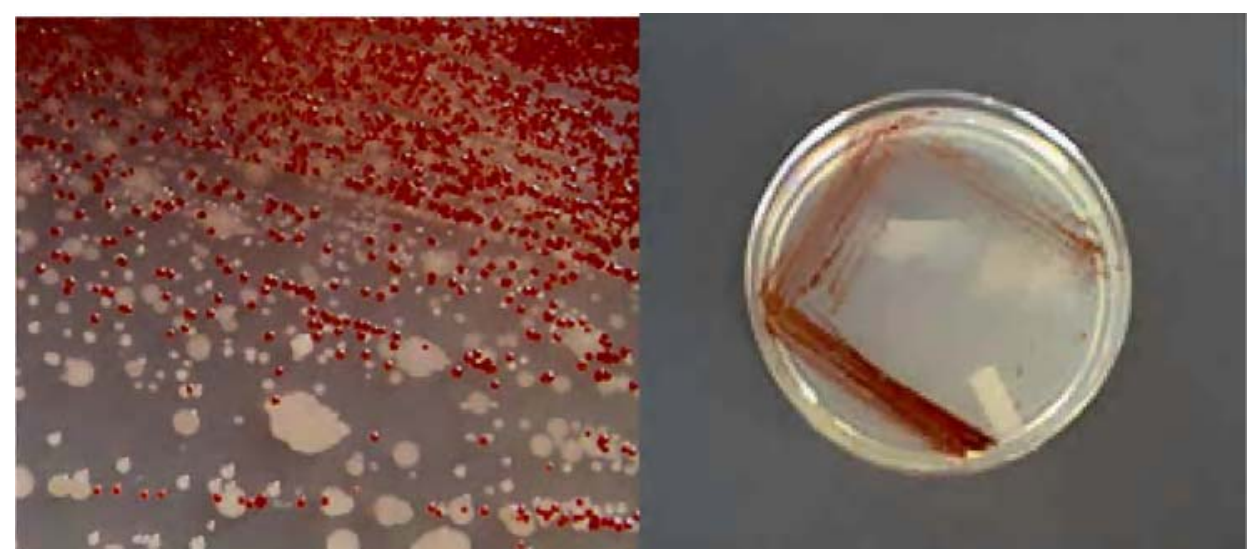

Fig. 1b: Z08 in solid medium (modified RCVBN medium with $2 \%$ agar)

intense radiation. All the vitamins of the basal minimal medium were necessary for its growth. In contrast, the bacteria could not take advantage of some tested inorganic compounds such as sodium, sodium thiosulfate and sodium oleate as summarized in Table 3. These results indicated that the isolate Z08 was most closely allied to $R$. sphaeroides although $R$.sphaeroides had recorded utilization of methyl cellulose and starch in complete anaerobic condition (Wilson et al., 2008). The isolate Z08 could neither metabolize methyl cellulose nor starch in micro aerobic environment. A suggestion is that the isolate metabolism favors soluble solids more than the insoluble matters micro aerobically.

The characteristic absorption peak of the isolate Z08 Micro aerobic photo heterotrophic growth of Z08
Table 3: Carbon source utilization of Z08 in modified RCVBN medium

\begin{tabular}{lcc}
\hline \multicolumn{1}{c}{ Organic compounds } & Isolate Z08 & $\begin{array}{c}\text { Rhodobacter } \\
\text { sphaeroides }\end{array}$ \\
\hline Ethanol & + & - \\
Fructose & + & + \\
Methyl cellulose & - & + \\
Sodium oleate & - & + \\
Starch & - & + \\
Glucose & + & + \\
Glycerol & + & + \\
Mannose & + & + \\
Sodium & - & - \\
Mannitol & + & + \\
Sorbitol & + & + \\
Sodium thiosulfate & - & - \\
\hline (+: utilization, - : no utilization) & &
\end{tabular}


isolate showed the cell suspensions to be red and the absorption spectra of the living cells showed maxima as summarized in Table 4. This showed that Z08 cell has bacteriochlorophyll $a$, which absorbs at 370 and $850 \mathrm{~nm}$, there was no absorption peaks for bacteriochlorophyll $b(400,605,840$ and 1025-1035 nm) and $c(660-668 \mathrm{~nm})$, the absorption at 450 and $570 \mathrm{~nm}$ indicated the presence of a major carotenoid pigment spheroidenone that absorbs at 450 and $570 \mathrm{~nm}$ respectively (Vladimir and Thamos, 1998; Madigan et al., 2000). These are characteristics features of a photo bacterium; therefore the isolate Z08 is a typical PSB. Furthermore, after the growth of the PSB isolate in pharmaceutical wastewater under micro aerobic - photo heterotrophic conditions, the cell suspensions were red and the absorption spectra of the living cells suspension also showed maxima at 370, 782, 800, 827 and 852 as shown in Fig. 2. The two main peaks at 370 and $850 \mathrm{~nm}$, which are allied to bacteriochlorophyll $a$, are characteristics of purple non-sulfur bacteria. These findings confirm previous work of the authors on this PSB specie (Madukasi et al., 2010), which denote that the isolate to be purple non-sulfur PSB.

\section{Z08 gene identification}

Application of GC-FAME (Gas chromatography of fatty acid methyl ester) analysis on the PSB isolate (Z08) identified the PSB as being closely related to $R$. sphaeroides (Rhodospirillaceae) with similarity indices of $0.85 \pm 0.05$. According to the Bergey's manual of systematic bacteriology and considering some of the physiological and biochemical tests performed, the strain Z08 was tentatively named $R$. sphaeroides. To further confirmation of the isolate identity, the 16SrDNA genes of the isolate was partially sequenced following Polymerase chain reaction (PCR) amplification and it was compared with the sequences deposited in the database. The phylogenetic tree (Fig. 3) showed that isolate Z08 was unidentified specie that was closely related to Rhodobacter sp. showing similarity of more than $95 \%$. The isolate was joined closely with $R$. sphaeroids species such as KD131, ATCC17029, IFO12203, SKO11 and DB803, respectively more than any other tested Rhodospirillaceae family

Table 4: The in-vivo spectrum of the isolate Z08 characteristic absorption peak

\begin{tabular}{ccccccccccc}
\hline Peak points No. & $210 \mathrm{~nm}$ & $245 \mathrm{~nm}$ & $260 \mathrm{~nm}$ & $340 \mathrm{~nm}$ & $370 \mathrm{~nm}$ & $450 \mathrm{~nm}$ & $570 \mathrm{~nm}$ & $850 \mathrm{~nm}$ & $980 \mathrm{~nm}$ \\
\hline 1 & 3.152 & 3.145 & 3.124 & 0.829 & 0.741 & 0.502 & 0.318 & 0.241 & 0.438 \\
2 & 3.110 & 3.117 & 3.062 & - & 0.747 & 0.505 & 0.316 & 0.241 & 0.436 \\
3 & 3.197 & 3.156 & 3.054 & 0.745 & 0.745 & 0.503 & 0.314 & $0 ? 240$ & 0.435 \\
\hline
\end{tabular}

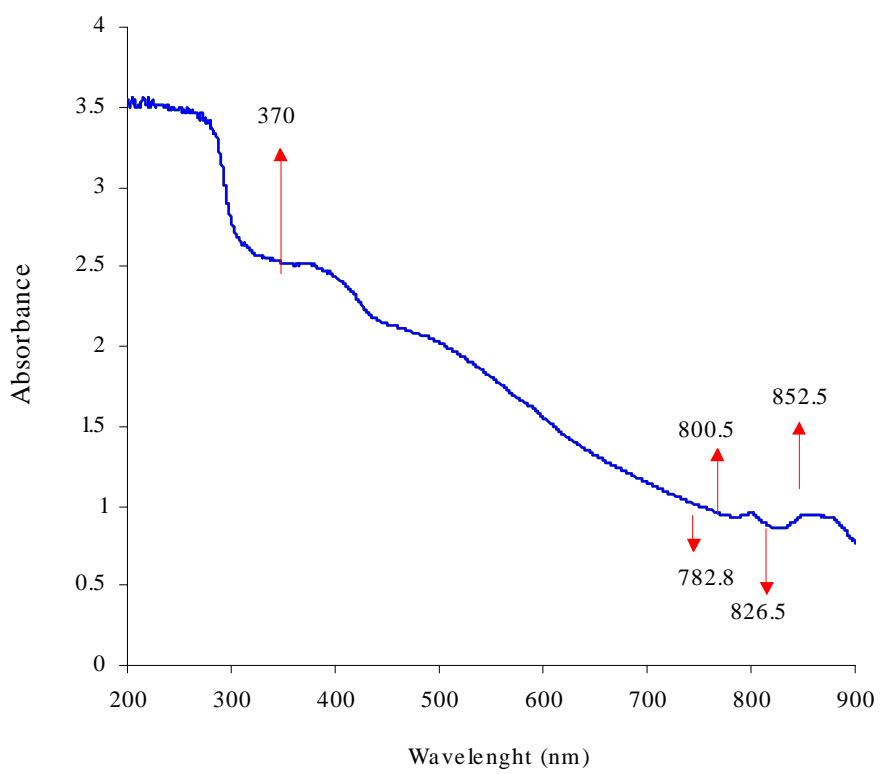

Fig. 2: In-vivo spectrum of the cell 


\section{E. I. Madukasi et al.}

(Fig. 3). It had been stated by some researchers that phototrophic bacteria especially the purple non-sulfur photosynthetic bacteria (PNSB) are widely distributed in soil, water and wastewater (Holt et al., 1994). In recent times, PNSB isolation has been made in wastewater, sludge and stagnant pond (Choorit et al., 2002; Kantachote et al., 2005; Myung et al., 2005). This is according to the authors search the most recent isolation of PNSB made from soil hence the name wild strain.

Application of the isolate Z08 to wastewater biodegradation

Pharmaceutical wastewater treatment

Different concentrations of real time pharmaceutical wastewater obtained from a medium scale factory in Harbin, China were inoculated with $20 \%$ inoculums of $\mathrm{Z} 08$ isolate. Incubations were for seven days at $30^{\circ} \mathrm{C}$ under the illumination of 3500lx incident light intensity utilizing incandescent lamp micro aerobically. The operation $\mathrm{pH}$ was neutral while the wastewater was centrifuged at $150 \mathrm{rev} / \mathrm{min}$ for $10 \mathrm{~min}$ before sterilization for $20 \mathrm{~min}$ at $0.103 \mathrm{MPa}, 121^{\circ} \mathrm{C}$. Intermittently at 3, 5 and $7 \mathrm{~d}$ respectively, the cell suspensions were withdrawn, centrifuged at $9000 \mathrm{rev} / \mathrm{min}$ for $15 \mathrm{~min}$, the COD reduction was measured using the supernatant solution and the sludge biomass yield calculated. Analyses of the treatments showed that 1:4 wastewater dilutions gave the best result with COD reduction of approximately $50 \%$, biomass yield of $780 \mathrm{mg} / \mathrm{L}$ dry cell weight (DCW) and specific growth rate of $0.015 / \mathrm{h}$ (Fig. 4), an indication that toxic ridden wastewater is best treated upon dilution. Although the COD reduction increased remarkably from $3 \mathrm{~d}$ to $7 \mathrm{~d}$ in all treatment concentrations (1:10, 1:4 and 1:1) before remaining unchanged, $5 \mathrm{~d}$ was considered the optimum retention time partly for economic reasons and also because the majority of the aggregated organic pollutants reduction (COD \%) were achieved within $5 \mathrm{~d}$ (Fig. 4). Choosing 1:4 diluted wastewater as the best condition for the

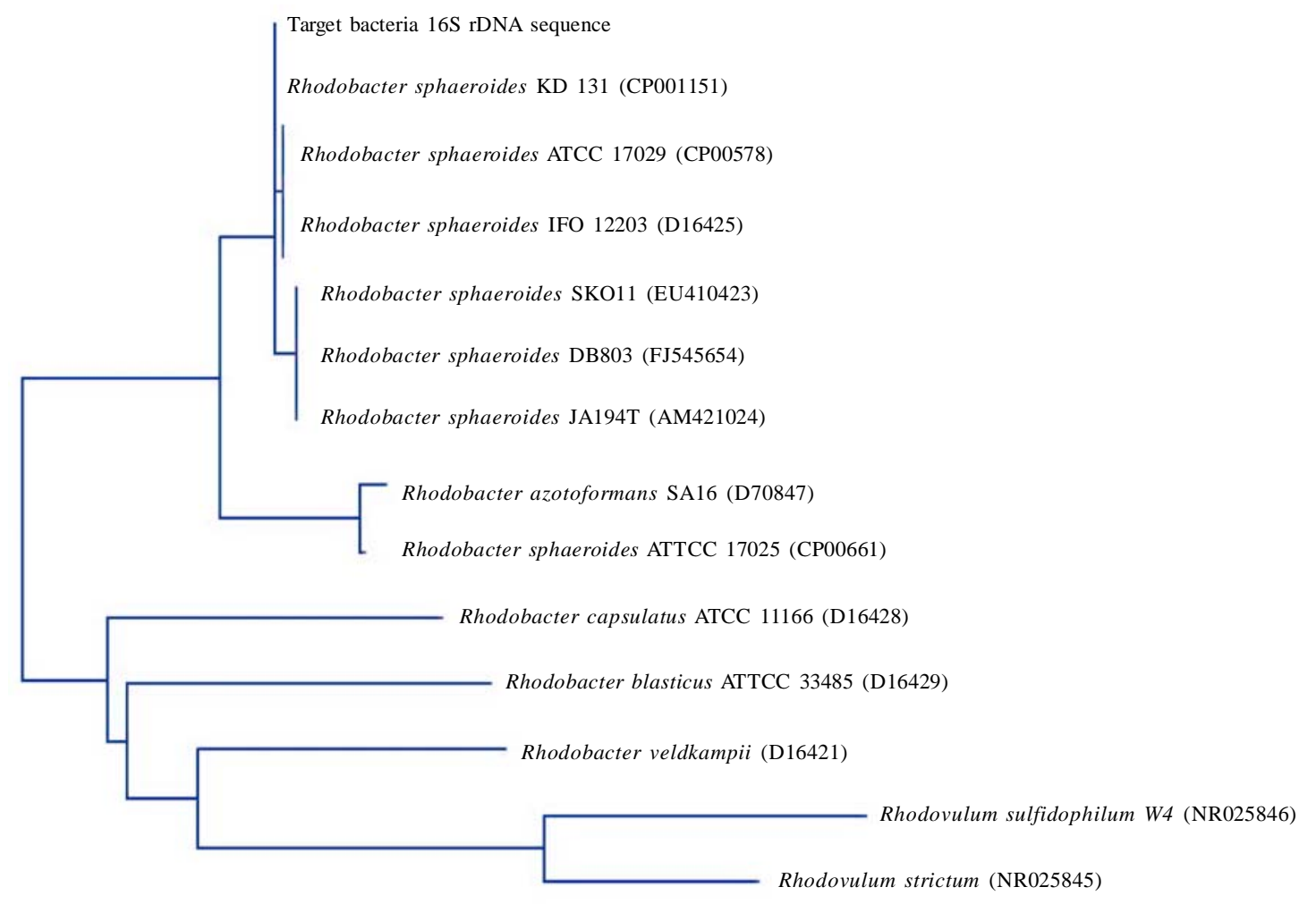

Fig. 3: Phylogenetic neighbor joining tree obtained with the 16SrDNA sequence of the isolate- Z08 and members of other related bacteria 
pharmaceutical wastewater to be biodegraded by Z08 was as a result that 1:4 dilution recorded a better biomass yield of approximately 0.2 in contrast to dilution 1:10 and the undiluted wastewater which recorded 0.12 and 0.13 , respectively. This is also an indication that 1:4 dilution of pharmaceutical wastewater coud lead to a better bioreactor conversion efficiency whereby the pollutants are converted to biomass using $\mathrm{Z} 08$ isolate. In addition, the results of initial experiements of authors showed that undiluted (1:1) wastewater leads to attainment of early stationary phase by the organism which stalled the growth.

Furthermore, the GC-MS spectrometry analyses of the influent pharmaceutical wastewater after initial centrifugation (150 rev/min, $10 \mathrm{~min}$ ), showed that the wastewater was characterized with persistent organic compounds which are lethal in nature. Some of the organic compounds are; eicosane, pentacosane, hexacosane, heptacosane, tetracosane and octacosane (spectra not shown). These compounds evidently indicated the content of the pharmaceutical wastewater which depicted the existence of hydrocarbons within the range of 18 - 40 carbon atoms. These compounds are resistant to biodegradation and accumulate in the environment with a resultant negative effect on the food web. Hydrocarbons have been demonstrated to inhibit enzyme activities as well as tendency for bioaccumulation (Sapana et al., 2008). The yielded effluent after $3 \mathrm{~d}$ treatment depicted some transformation of the persistent organics to less lethal compounds such as 1, 2-benezenedicarboxylic acid and butyl 2-methylpropyl ester. Considering the fact that pharmaceutical wastewater contains large quantities of refractory organic toxic substances (Fent et al., 2006; Oktem et al., 2007; Ren et al., 2008; Yang et al., 2009; Giri et al., 2010) as well as residues of antibiotics, sustenance of pollutants reduction and transformation of the recalcitrant compounds by the isolate Z08 in the toxic ridden wastewater up to $7 \mathrm{~d}$ before decline suggested that the isolate Z08 has some toxic tolerance level with potentials in detoxification of toxic pollutants.

\section{Soybean wastewater treatment}

Non-sterilized soybean wastewater was inoculated and treated at the same conditions as stipulated in section 4.1 (i.e., the pharmaceutical wastewater treatment) under natural light intensity. The biomass yield was measured every $12 \mathrm{~h}$ till $168 \mathrm{~h}$ during the treatment. Treatment of different soybean wastewater concentrations without lyses at natural light intensity,

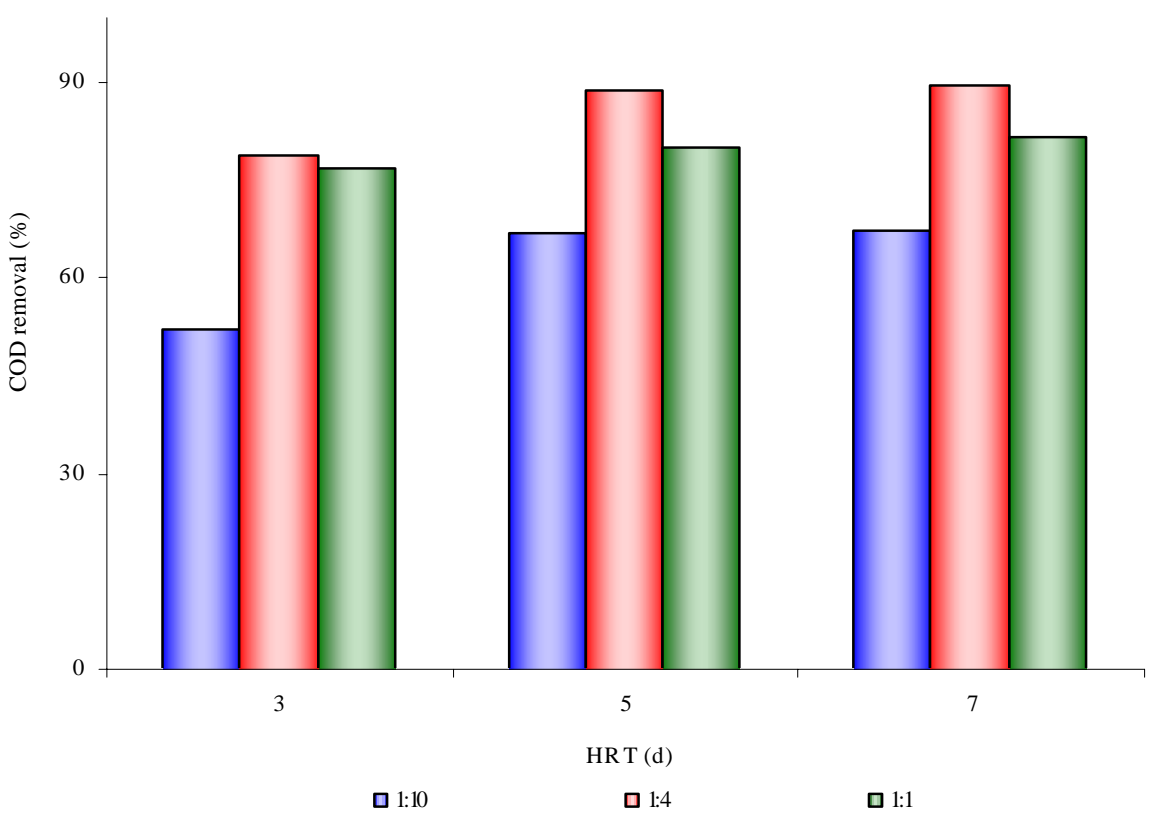

Fig. 4: Effect of dilution on COD removal \% at 3, 5 and $7 \mathrm{~d}$ retention $($ Initial COD; $1: 10=1000 \mathrm{mg} / \mathrm{L}, 1: 4=2500 \mathrm{mg} / \mathrm{L}$ and $1: 1$ (non-diluted) $=8400 \mathrm{mg} / \mathrm{L}$ ) 
recorded significant COD reduction after $72 \mathrm{~h}$ cultivation; extension of the treatment time had no effect on the COD reduction. At $72 \mathrm{~h}$ the aggregated COD reduction was $83 \%, 90 \%, 80 \%$ and $74 \%$ at the various foods to microorganism's ratio (F/M) of 40, 20, 10 and 2 respectively (Fig. 5). The specific growth rate (ca. 0.025/h) equally remained constant after $3 \mathrm{~d}$ Hydraulic retention time (HRT) (data not shown). Therefore, it is concluded that the isolate Z08 could directly treat organic ridden wastewater without lyses under micro aerobic light condition without additional cost. This ascertion was as a result of the fact that the soybean processing wastewater, like other organic wastewaters, is rich in monosaccharide, oligosaccharides, K, P, Ca, Fe, vitamins, organic acids, water-soluble protein, amino acids, lipids and other nutrients. However, in the conventional activated sludge process (aerobic treatment), these organic nutrients increase the organic load and operational costs of the treatment processes cum wastage of valuable nutrients (Lerner et al., 2007; Zhu et al., 2008). In this study, the biomass yield was comparable to the yield produced by the conventional aerobic activated sludge (Table 5) without additional cost. This is an indication that the isolate Z08 could produce enormous biomass via pollutants degradation at less available oxygen. Also this treatment process is more effective than the conventional activated sludge treatment process solely because Z08-treatment has the potential for single cell protein recovery via harvest of the biomass at the same time achieving wastewater purification goal at low energy cost and the biomass could be utilized directly as soil conditioner or in animal feed supplement. In contrast, the conventional activated sludge yields hazardous sludge which demands additional treatment prior to usage (Zhu et al., 2008). PSB have been reported to be rich in vitamins and proteins (Kobayashi and Tchan, 1973; Imhoff, 1992; ) hence a good source of single cell protein recovery. In addition, analysis of the accumulated biomass showed the crude protein content to be $42 \%$ depicting single cell protein production.

Table 5: The apparent PSB yield in the soybean wastewater treatment process

\begin{tabular}{lcccc}
\hline No. & $\begin{array}{c}\text { Influent COD } \\
(\mathrm{mg} / \mathrm{L})\end{array}$ & $\begin{array}{c}\text { Effluent COD reduction } \\
(\mathrm{mg} / \mathrm{L})\end{array}$ & $\begin{array}{c}\text { Cell biomass } \\
(\mathrm{mg} / \mathrm{LDCW})\end{array}$ & $\begin{array}{c}\text { Bacteria yield } \\
(\mathrm{mg} / \mathrm{L} \mathrm{dry} \mathrm{weight} / \mathrm{mg} / \mathrm{L} \mathrm{COD})\end{array}$ \\
\hline 1 & 405 & $202.0 \pm 21$ & $77.8 \pm 0.22$ & 0.385 \\
2 & 1980 & $1110.5 \pm 23$ & $420.7 \pm 0.25$ & 0.379 \\
3 & 4100 & $2100.4 \pm 23$ & $800.0 \pm 0.38$ & 0.381 \\
4 & 8300 & $4260.6 \pm 32$ & $1585.0 \pm 0.41$ & 0.372 \\
\hline
\end{tabular}

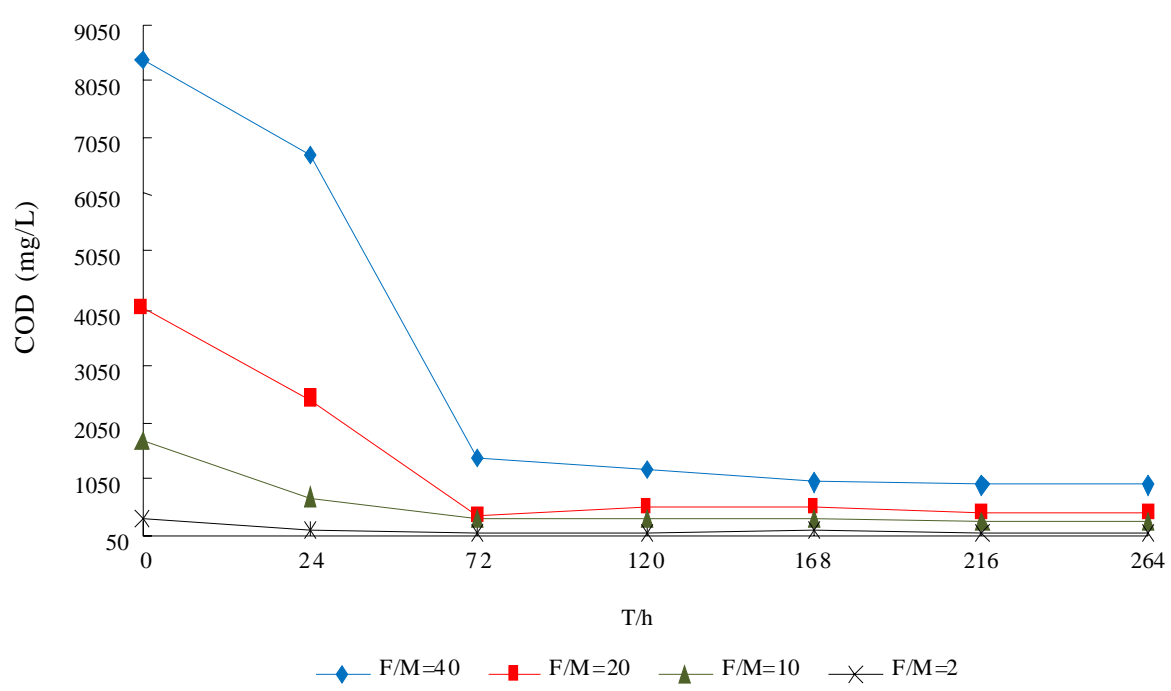

Fig. 5: COD reduction patterns in different concentrations of soybean wastewater 


\section{CONCLUSION}

The wild strain PSB isolate named Z08 is a PNSB which was identified as been closely aligned to $R$. sphaeroides by $16 \mathrm{SrDNA}$. This study showed that PSB species are numerous and many species are yet to be isolated and identified accordingly. It is also an indication that prokaryotes are easy to multiply particularly the heterotrophic that blooms in intense radiation utilizing varied organic substrates. Furthermore, the entire study suggested that wild strain PSB could be isolated in any suitable environment for adaptation to both organic and inorganic contaminate reductions hence the isolate utilization of micro / macro compounds. Lastly, Z08 growth in toxic ridden pharmaceutical wastewater showed that the new PSB isolate has some toxic tolerance level and could be applied to bioremediation of contaminated environment. While the high COD removal and biomass yield recorded during soybean wastewater treatment under natural light intensity suggested its potential in high organic strength wastewater purification with the recovery of useful resource without additional cost. The crude protein content of the soybean biomass was approximately42\%, which was an indication of single cell protein production.

\section{ACKNOWLEDGEMENTS}

The authors thank the financial supports from National Natural Science Foundation of China (50978072) and Chinese Ministry of Science and Technology (2008ZX07421-003). The authors also thank the Reviers and the Editorial board for their comments and contribtions.

\section{REFERENCES}

Altschul, S. F.; Gish, W.; Myers, E. W.; Lipman, D. J., (1990). Basic local alignment search tool. J. Mol. Biol., 215 (3), 403-410 (8 pages).

Banerjee, S.; Azad, S. A.; Vikineswary, S., Selvaraj, O. S.; Mukherjee, T. K., (2000).Phototrophic bacteria as fish feed supplements. Asian-Austral. J. Anim. Sci., 13 (7), 991-994 (4 pages).

Chae, S. A.; Hwang, F.; Akira, H., (2006). Single cell protein production of Euglena gracilis and carbondioxide fixation in an innovative photobioreactor. Bioresour. Tech., 97 (2), 322-329 (8 pages).

Choorit, W.; Thanahoset, P.; Thongpradistha, J.; Sasaki, K.; Noparatnaraporn, N., (2002). Identification and cultivation of photosynthetic bacteria in wastewater from a concentrated latex processing factory. Biotech. Lett., 24 (13), 1055-1058 (4 pages).
Ding, C., (2008). Experiments on the biodegradation of phenol wastewater by immobilized photosynthetic bacteria. Water Resour. Prot., 24 (3), 93-95 (3 pages).

Fain, M. G.; Haddock, J. D., (2001). Phenotypic and Phylogenic characterization of Burkholderia (Pseudomonas) sp. Strain LB400. Curr. Microbiol. 42 (4), 269-275 (6 pages).

Fent, K.; Weaton, A. A.; Caminada, D., (2006). Ecotoxicology of human pharmaceuticals. Aquat. Toxicol., 76 (2), $122-$ 159 (36 pages).

Giri, R. R.; Ozaki, H.; Ota, S.; Takanami, R.; Taniguchi, S., (2010). Degradation of common pharmaceuticals and personal care products in mixed solutions by advanced oxidation techniques. Int. J. Environ. Sci. Tech., 7 (2), 251160 (10 pages).

Hall, T. A., (1999). BioEdit: A user-friendly biological sequence alignment editor and analysis program for Windows 95/98/ NT. Nucl. Acids. Symp. Ser., 41 (2), 95-98 (4 pages).

Holt, J. G.; Krieg N. R.; Sneath P. H. A.; Staley J. T.; Williams S. T., (1994). Bergey's manual of determinative Bacteriology. $9^{\text {th. }}$, Baltimore; the Williams Wilkins Co.

Howard, G., (1987). The world of microbes. The Benjamin Cummings publishing, Inc.

Imhoff, J. F., (1992). Taxanomy, phylogeny and general ecology of anoxygenic phototrophic bacteria. Mann. N. H.; Carr, N. G., (Eds.). Bergey's manual of determinative bacteriology. Plenum press New York.

Kantachote, D.; Salwa, T.; Kamontam, U., (2005). The potential use of anoxygenic photosynthetic bacteria for treating latex rubber sheet wastewater. Electron. J. Biotech., 8 (3), 314-323 (10 pages).

Koblizek, M.; Falkowski, P. G.; Kolber, Z., (2006). Diversity and distribution of photosynthetic bacteria in the black sea. Deep Sea Res., 53 (17-19), 1934-1944 (10 pages).

Kosamu, I. B. M.; Obst, M. (2009). The influence of picocyanobacterial photosynthesis on calcite precipitation. Int. J. Environ. Sci. Tech., 6 (4), 557-562 (6 pages).

Lane, D. J., (1991). 16S/23SrRNA sequencing. Stukebrandet, E.; Goodfellow, M., (Eds.), Nucleic acid techniques in bacterial systematic. John Wiley and Sons, New York.

Lerner, M.; Stahi, N.; Gali,l N., (2007). Aerobic vs. anaerobicaerobic biotreatment: Paper mill wastewater. Environ. Engin. Sci., 24 (3), 277-285 (8 pages).

Madigan, M. T.; Jung, D. O.; Woese, C. R.; Achenbach, L. A., (2000). Rhodoferax antarcticus sp. nov., a moderately psychrophilic purple nonsulfur bacterium isolated from an Antarctic microbial mat. Arch. Microbiol., 173 (4), 269277 (8 pages).

Madukasi, E. I.; Dai, X. I.; Chunhua, H.; Zhou, J.J., (2010). Potentials of phototrophic bacteria in treating pharmaceutical wastewater. Int. J. Environ. Sci. Tech., 7 (1), 165-174 (10 pages).

Myung, K. K.; Choi, K. M.; Yin, C. R.; Lee, K. Y.; Im, W. T.; Lim, J. H.; Lee, S. T., (2004). Odorous swine wastewater treatment by purple non-sulfur bacteria, Rhodopseupdomonas Pulustris, isolated from eutrophicated ponds. Biotech. Lett., 26 (10), 819-822 (4 pages).

Oktem, Y. A.; Ince, O.; Sallis, P.; Donnelly, T.; Ince, B. K., (2008). Anaerobic treatment of a chemical synthesis-based pharmaceutical wastewater in a hybrid up flow anaerobic sludge blanket reactor. Bioresour. Tech., 99 (5), 1089-1096 (7 pages).

Okubo, Y; Hiroyuki, F; Akira, H., (2006). Characterization of 


\section{E. I. Madukasi et al.}

phototrophic purple non-sulfur Bacteria forming colored microbial mats in a swine wastewater Ditch. Appl. Environ. Microbiol., 72 (9), 6225-6233 (9 pages).

Ren, N.; Chen, Z.; Wang, A.; Zhang, Z. P., Yue, S., (2008). A novel application of TPAD-MBR system to the pilot treatment of chemical synthesis-based pharmaceutical wastewater. Water Res., 42 (13), 3385-3392 (8 pages).

Saitou, N.; Nei, M., (1987). The neighbour-joining method: A new method for reconstructing phylogenetic trees. Mol. Biol. Evol., 4 (4), 406-425 (20 pages).

Sapana S.; Sujata B.; Amruta T.; Kalal, K.; Phalgune, U. D.; Deshpande, N. R., (2008). GC-MS Study of hydrocarbons- A Renewable Biofuel with high calorific value from aerial roots of ficus Benghalensis Linn. Electron. J. Environ. Agr. Food chem., 7 (3), 2743-2748 (6 pages).

Sasser, M., (1990). Identification of bacteria by gas chromatography of cellular Fatty acids. MIDI technical note 101. MIDI, Newark, Del. USA.

Siefert, E.; Irgens, R. L.; Pfennig, N., (1978). Phototrophic purple and green bacteria in a sewage treatment plant. Appl. Environ. Microb., 35 (1), 38-44 (7 pages).

Ventosa, A.; Quesada, E.; Rodriguez-Valera, F., (1982). Numerical taxanomy of moderately halophilic Gramnegative rods. J. Gen. Microbiol., 128 (9), 1959-1968 (10 pages).

Vladimir, Y.; Thomas, B. J., (1998). Isolation of aerobic anoxygenic photosynthetic bacteria from black smoke plume waters of the Juan de Fuca ridge in the Pacific Ocean. Appl.
Environ. Microb., 64 (1), 337-341 (5 pages).

Wilson, S. M; Gleistan, M. P; Donohue, T. J., (2008). Identification of proteins involved in formaldehyde metabolism by Rhodobacter sphaeroides. Microbiology., 154 (3), 296-305 (8 pages).

Yang, Y.; Wang, P.; Shi, S.; Liu, Y., (2009). Microwave enhanced Fenton-like process for the treatment of high concentration pharmaceutical wastewater. J. Hazard. Mater. 168 (1), 238-245 (7 pages).

Yegani, R.; Satoshi, Y.; Kazunori, M.; Tomoshisa, K; Shigeo, K., (2005). Improvement of growth stability of photosynthetic bacterium Rhodobacter capsulatus., J. Biosci. Bioeng., 100 (6), 672-677 (7 pages).

Yousefi Kebria D.; Khodadadi, A.; Ganjidovst, H.; Badkoubi, A.; Amoozegar, M. A., (2009). Isolation and Characterization of a novel native Bacillus strain capable of degrading diesel fuel. Int. J. Environ. Sci. Tech., 6 (3), 435-442 (8 pages).

Zhang, X. X.; Zhao, D. Y.; Wang, Z. X.; Wu, B.; Li, W. X.; Cheng, S. P. (2009). Environmental biological model ased on optimization of activated sludge process. Int. J. Environ. Sci. Tech., 6 (1), 69-76 (8 pages).

Zhu, F. G.; Li, J. Z.; Wu, P.; Jin, H. Z.; Wang, Z., (2008). The performance and phase separated characteristics of an anaerobic baffled reactor treating soybean protein processing wastewater. Bioresour. Tech., 99 (17), 8027-8033 (6 pages).

\section{AUTHOR (S) BIOSKETCHES}

Madukasi, E. I., M.Sc., Research scientist, Federal Institute of Industrial Research, Lagos, Nigeria. Ph.D., Research student, Department of Municipal and Environmental Engineering, Harbin Institute of Technology, China. Email: madify2002@yahoo.com

Chunhua, H., B.Sc., Senior student, Department of Municipal and Environmental Engineering, Harbin Institute of Technology, China. Email: huachun@yahoo.com.com.cn

Zhang, G., Ph.D., Lecturer, Department of Municipal and Environmental Engineering, China. Email: gmgwen@gmail.com 